\title{
'The ocean is our only highway and means of communication': Maritime Culture in Colonial Southern New Zealand
}

\author{
MICHAEL J. STEVENS
}

Referring to the enormous changes that long-haul jet airline transportation has effected on New Zealand's socio-economic fabric, Sir Tipene O'Regan commented in 2003 that, "we are no longer a maritime nation in the way we were'.' I agree with this assessment. I would go further, though, and suggest that the 'big ol' jet airliner' has carried us so far away ${ }^{2}$ from our maritime origins that very few New Zealanders, especially those born into Generation X and beyond, have an understanding of the ocean's contemporary importance, let alone its earlier dominance. Those who have an awareness of these things, unsurprisingly, live or work in coastal ports. Many of these people are Māori.

Like O'Regan, whose mother was from Bluff (the daughter of a Kāi Tahu master mariner), ${ }^{3}$ the Māori people I refer to are predominantly descended from tākata-pora (boat-people/ship-men): nineteenth-century 'Euroamerican' sealers, whalers, traders and sailors. ${ }^{4}$ Several ports in colonial southern New Zealand - for example Moeraki, Bluff and Riverton - grew out of precolonial shore-whaling stations, which numbers of Māori men and women worked at or lived on (hence Native Reserves being set aside in their vicinity). The children and grandchildren of these people found employment in turn in the same geographical environments, whose 'middle-ground' equilibriums were economically, physically and culturally transformed by the colonial encounter. In my view, therefore, New Zealand's maritime history is very much Māori history, and vice versa. Can we therefore read the relative absence of maritime history, at the popular level at least, as an example of Māori marginalization? Perhaps. However, New Zealand history and Māori history have been subjected to sustained reassessment over the last 30 years. Moreover, Māori authors and kin groups have often been at the forefront of this. Even in such instances, though, it is rare to find the ocean - let alone a global view of it - anchored at the centre of things. How do we account for this? One reason might be the long shadow of the nineteenth-century 
'land wars' and the 'land claims' discourse that surrounds Treaty politics and the work of Waitangi Tribunal.

Speaking of the Tribunal, Kerry Howe directly implicates it in relation to New Zealand historians turning away from Pacific history. According to him, in the early 1970s an emerging body of scholarship was bringing New Zealand and Pacific history into a single analytical frame. Unfortunately, this approach was discarded before it fully took root, however, and he identifies the rubric of the Treaty of Waitangi as a key reason for this. ${ }^{5}$ Damon Salesa has made similar remarks and argued that Māori history, politics and people separated themselves off from those in and of the Pacific. ${ }^{6}$ The work of Tongan scholar Epeli Hau'ofa supports such a view. In his oft-quoted article 'Our Sea of Islands', he introduced the idea of 'world enlargement'? This essentially referred to the phenomenon of Pacific Island people travelling, living and working all around the world, and the reciprocal supply-chain networks that this enables. Hau'ofa argued, quite convincingly, that this state of affairs was both overlooked and misunderstood by the tangled matrix of politicians, aid donors and academics. The other key point he made, of particular relevance to this article, was that the origins of the process he referred to were pre-European. European contact extended it by way of sailing and then steam-powered ships, and, more recently, jet-air travel. His remarkable essay, written with New Zealand very much in mind, could not have emerged from many contemporary Māori scholars. Its gaze was outward and attuned to interconnections, whereas the scholarship emanating out of New Zealand was inward-looking and disengaged from the wider world. Evidence in support of this position is the fact that the article seems not to have received the purchase it should have within considerations of the post-European Māori past.

Although I have suggested that the relative absence of the ocean compared with land in the New Zealand imaginary is in part due to Treaty discourse, I am well aware, and we should all bear in mind, that several early claims lodged with the Waitangi Tribunal were Māori protestations about the contamination of coastal marine areas. We should also bear in mind that Te Kerēme, the Ngāi Tahu claim, was presented in two tribunal reports: basically, one each for the land and the sea. If nothing else, one wonders why the coast, at least, continues to be largely absent from understandings of New Zealand and Māori history, given the highly politicized question of aboriginal rights to the foreshore and seabed. Having raised its spectre, I should point out that this article does not directly engage with Treaty historiography. Spared from the tyranny of relevance, I am not party to the 'marriage of inconvenience' ${ }^{8}$ between historical scholarship and juridical process, and my research interests and methodologies reflect this. 
What this article does is simply respond to calls for a greater consideration of New Zealand's ports and chart some of the results that this offers up. ${ }^{9}$ One of these is the prospect of a Māori history more fully 'in the round' ${ }^{10}$ For while we certainly need to know more about Māori in unexpected places, ${ }^{11}$ there is much to learn about Māori in expected places, and maritime settings (partly for reasons outlined above) are chief amongst these. Geographically, this article focuses on southern New Zealand, and the port of Bluff - my hometown - in particular. That being the case, the article also continues the task of writing Kāi Tahu back into Māori history from the extreme edges of colonial marginalization.

While my article is concerned with the colonial era, which, with respect to Bluff, might be dated as the period 1856-1907, ${ }^{12}$ I also look at Bluff beyond these years. Doing so, I think, helps us to better understand the colonial encounter there. I have argued elsewhere that muttonbirding constituted (and continues to constitute) a key plank in the alternative modernity of southern Kāi Tahu..$^{13} \mathrm{I}$ am, however, mindful that this activity occupies only two months of the year, at most. This article is therefore the beginning of an exploration of the other ten months. Fishing and oystering, but also shearing, were important seasonal activities. Related things such as cargo handling and boat building were likewise central features of southern Kāi Tahu colonial life throughout and beyond the colonial era. To what extent this stemmed from tākata-pora influence or an underlying Māori predilection for all things aquatic is moot. Having said that, it is worth identifying and analyzing some 'Kāi Tahu' ideas, practices and artefacts that have tākatapora origins. Oyster boats not putting to sea on a Friday, a prohibition on whistling at sea for fear of bringing on a wind, and carrying a potato in one's pocket when entering a new natural environment are all examples. These cultural markers, I think, are one way of capturing a little more of our tākata-pora forebears, who were mostly illiterate and who, like their Kāi Tahu wives, are also often little more than ghosts in the colonial archive.

Frances M. Steel and Tamson Pietsch have each urged researchers to take seriously the idea that the ocean is not an empty or dividing space, but, rather, a connecting and deeply historical one. ${ }^{14}$ This is especially true of the vessels that cross it. ${ }^{15}$ As Steel puts it, in the context of Pacific historiography we need to shift our 'frame of enquiry off-shore to the oceanic spaces inbetween, to more fully conceptualize and materialize ships as sites of history and to understand the significance of "sea time" for a range of historical actors". ${ }^{16}$ I am deeply supportive of this approach. However, this article does not focus on an oceanic setting, but rather a littoral one. Michael N. Pearson defines the littoral as 'the coastal zone, the beach, and some indeterminate frontier on land' and asserts that attempts 'to specify the nature of littoral societies is central as we try to advance our exploration of seas and oceans.' ${ }^{17}$ 


\section{'New people'}

Erik Olssen describes the 1844 Ōtākou purchase, the first major land transaction entered into by Kāi Tahu representatives and Crown agents, as preparing 'the way for a rupture in the history' of southern New Zealand. ${ }^{18}$ Up until that point, Kāi Tahu kin groups and tākata-pora had lived and intermarried in multiple coastal pockets across the region, for several decades in some instances. According to Olssen, the children born to these 'two hunting tribes', which he termed 'new people', did not constitute an introduction to what followed but were rather a separate play that was quickly dismissed from centre-stage. ${ }^{19}$ Between 1848 and the early 1860 s, this composite culture was overwhelmed, literally, by tides of European settlers who were intent on, and largely successful in, building a neo-Europe in southern New Zealand. By 1867 the combined population of Otago and Southland was $56,000,{ }^{20}$ while the total number of Kāi Tahu in the same time and place probably numbered less than $1000 .{ }^{21}$

As European interest in New Zealand was firmly redirected away from extractive coastal marine industries and towards sedentary agricultural settlement, some tākata-pora had the inclination and capacity to recast themselves in the colonial society that emerged around them. Others, though, many who fitted the description of them as 'escaped convicts, whalers, shipwrecked sailors - the flotsam and jetsam of the Pacific', as an empire historian put it in 1922, ${ }^{22}$ had less success. As for their middle-ground progeny, the genesis of present-day Kāi Tahu, they were not included in colonial society on their own terms, and often not at all. True, as Angela Wanhalla has shown us, some of these 'half-castes', to use the parlance of the day, and their children in turn, occasionally melted into the lower rungs of European southern New Zealand. ${ }^{23}$ For my part, though, I am interested in those who did not do that. I am interested in those who we might call 'hau-kaik' people; and in particular, where and how they lived.

Though dismissed from centre-stage, these embodiments of what Olssen called an 'embryonic Ngaitahu-Pakeha culture' did not simply vanish, nor enter a tomb to await resurrection in the Māori renaissance. They, and their mixed culture, retreated, consolidated, and persisted in several coastal settings. Bluff was one of these. The ethnographer Herries Beattie, who visited and befriended Bluff-based southern Kāi Tahu, described the small related settlements like Moeraki, Puketeraki and Colac Bay as 'the parts that sheltered the Natives', where they 'preserved their racial identity' and lived 'quiet lives . . . little noticed by the newspapers or the public'. ${ }^{24}$ Contrary to popular opinion, and despite their 'noticeable invisibility' in large parts of southern New Zealand, Beattie assured his readers, 'the remnant of the Maoris' were not altogether 'lost in the inflowing white tide'. 


\section{Old habits}

In Bill Dacker's evocative phrase, Bluff became a key site of 'holding on'. ${ }^{25}$ Underwritten by the remarkable seasonal tītī harvest - 'An industry peculiar to Bluff and the southernmost part of New Zealand'26 - and kindred mahika kai (wild-food harvesting) practices that found relevance in the colonial economy (such as sealing, fishing, fish processing and oystering), southern Māori traditions persisted in a built environment which nonetheless made it clear that it was a British colonial outpost. So, while Bluff was the place from which Sir Baden Powell departed after his national tour of New Zealand in 1913, and Queen Elizabeth II after hers in 1954, the port town is a lot less 'British' than it might at first appear. Sometimes the Māori presence was obvious. For instance, referring to the lead-up to muttonbirding, Beattie wrote in 1954 that 'you can pick out the Maori residences at the southern ports by the line of kelp bladders in the yard'. ${ }^{27} \mathrm{He}$ was referring to pōhā-hau and the manufacture of kelp bags commonly used to hold preserved tîtī.

Other, less obvious, traces of Māori life-ways in and around colonialera Bluff remain too. A few years ago, for example, I found an old photo buried in the informal archive at the Bluff Maritime Museum. This shows a beach-side freezing works - itself a symbol of Kāi Tahu land loss and the agro-ecological transformation of Southland - decorated with at least two Union Jacks, the New Zealand ensign, various other pennants and native New Zealand fern trees to celebrate the end of the Boer War. ${ }^{28}$ Beneath this tribute to empire was a small shack, the so-called Māori Boarding House. This was an important tauraka-waka (landing place) and nohoaka (resting place) used by Kāi Tahu travelling to and from Rakiura, the Tîtî Islands or Ruapuke Island, and the mainland. Kāi Tahu sought refuge in this building (from pistol fire, no less) when relations with visiting sailors turned sour; ${ }^{29}$ it also seems to be where the Kāi Tahu chief Topi Patuki once hosted Te Whiti and Tohu Kakahi, the prophetic Taranaki leaders. ${ }^{30}$ In short, this was a communal space which functioned very much as a marae complex does. As the port grew, though, substantially on the back of frozen meat exports, the house gave way to land reclamation and infrastructure such as railways. As compensation - politically advisable if not legally enforceable - the government and/or the local Harbour Board purchased a weatherboard villa on a suburban section for local Māori use and transferred ownership accordingly. ${ }^{31}$ Although direct access was thus lost to the foreshore, the new building was named Tarere ki Whenua Uta. ${ }^{32}$ This phrase, connected as it is to the southern traditions of the famed Tamatea, simultaneously asserted the ongoing relevance of pre-European Māori tradition and a view of the world framed by looking at the land from the sea, as opposed to the other way around as many contemporary Pākehā viewed it, if indeed they viewed 
it at all. Colloquially referred to as the Māori House, and later, the Little House, Tarere ki Whenua Uta still stands (in an understandably modified state) and forms part of the grounds of Te Rau Aroha marae.

At the time of writing, my maternal grandparents live directly opposite the Little House. As noted by the likes of Beattie decades earlier, their house is adorned with pōhā-hau each February. It is, however, one of the last, and often the only, house to be found this way. And yet, with a surname like Metzger my grandfather is clearly not one of the 'last of the old-time Māori, to borrow a phrase from late nineteenth-century New Zealand. As a visitor to the town noted in 1937 - when my grandfather was five years old - 'Maoris are plentiful in Bluff, though there are few of them now who do not show some admixture of pakeha blood. ${ }^{33}$ As the name implies, my grandfather's paternal great-grandfather was a German settler. This man, Joseph Metzger, originally from Württemberg, emigrated to Southland from Bradford, England, via Australia in 1872. A butcher by trade, Joseph met and married Ernestine Radka, a Polish emigrant who hailed from Posen (present-day Poznań) and who had also recently emigrated to Southland. ${ }^{34}$ Joseph became a prominent businessman and local body politician and is best remembered as a publican. The Bay View Hotel, which he founded, is still a going concern on Bluff's main street (although very little of the bay is now visible from the premises due to an imposing cool storage facility which stands between it and the foreshore). However, Joseph also had interests in the inshore fishing industry and founded the New Zealand Fishing Company. He owned various fishing boats and had fish receiving sheds erected at Colac Bay, Ruapuke and Stewart Island. Fish from these depots was shipped to Bluff, frozen down and shipped to an agent in Melbourne. ${ }^{35}$ This was all made by possible by a regular Melbourne-Bluff route which operated throughout the latter decades of the nineteenth century and the first decades of the twentieth century.

\section{'Of the blood'}

Bluff was connected directly to Melbourne and other international ports besides, including London, from the 1860s. Indeed, in his report to the Admiralty of the 1850 hydrological survey of Foveaux Strait undertaken by the Acheron, Captain John Lort Stokes noted that Bluff 'is fully a fortnight near [sic] to England than any other portion of New Zealand now under colonization' ${ }^{36}$ About a century later Bluff was the largest frozen mutton and lamb exporting port in the country. ${ }^{37}$ Peter Gibbons was right to underscore that 'before it was any kind of political and constitutional entity . . New Zealand was a series of opportunities for circulating artefacts within the world system and ports were locations for exchanges' ${ }^{38}$ However, in its early 
colonial days, shipping did not just connect New Zealand's multiple ports with foreign ones and thus the world at large; it actually connected them with each other. As Tony Ballantyne recently highlighted, prior to strong central government and its significant investment in road, bridge and railway building 'New Zealand' was simply a chain of disparate littoral settlements linked by water. ${ }^{39}$ In any case, as intimated at the outset of this article, it pays to remind ourselves that before we had airports, we had ports. This is clearly an exercise in stating the obvious; however, I think we are prone to forget that much of the infrastructure and services that exist at airports today used to exist on our coasts. The controlled chaos and two-way traffic of goods and people one sees at an airport, the mediating presence of airport employees and customs officers, and vendors of food and accommodation all used to exist on our shores. More than that, they did so for the greater part of New Zealand's history.

Whether it was viewed it as bridge or barrier, for many nineteenth-century Britons in the metropole, and most of them on the various peripheries of empire, the ocean was ever present in their material and discursive worlds. Thus, in the 1899 Otago Witness Christmas annual one reporter described 'the toll that the sea demands' as 'the price of empire'. Examining the 'great Pacific rollers as they break upon our island shores', the author was 'moved to tell of . . . victories . . . which are fought without tuck of drum and blare of trumpet, and all the pomp and majesty of war'. He explained that everything has a price, which must be paid, and 'Here in "the utmost limits of the world," where the ocean is our only highway and means of communication with other men, that ocean demands a heavy toll.' $\mathrm{He}$ therefore proceeded to 'tell of the storm and stress of tortured humanity; of ships that have foundered in the wild war of the elements', and listed all known shipwrecks in southern New Zealand. For this person, 'we "of the blood" are born sea-kings and vikings, and glory in the fact'. ${ }^{40}$

Colonial Otago's enlightened Protestants had earlier reflected on the perils of the sea. In 1875 the Evangelist, an important periodical then under the editorship of the remarkable Donald McNaughton Stuart (a key player in the founding of the University of Otago), reported at length on the destruction of an emigrant ship that caught fire off the Cape of Good Hope, resulting in the death of all but three of the 460 people on board. Pointing to an ongoing belief in special providence, the column stated that 'It may well be time for us to ask ourselves whether we give to travellers by water, who are exposed to many casualties, the place in our private family and public prayers to which they are entitled.' Church rulers were thus urged to remind their charges 'of these and similar duties which we are apt to overlook'. ${ }^{41}$ The first resident foreign missionary at Foveaux Strait, the Reverend 
J.F.H. Wohlers, who established a mission on Ruapuke in 1844 and was a regular contributor to the Evangelist and the Otago Institute, similarly spoke about the importance of ships and their crew. In the 1895 English translation of his memoirs he explained that, 'The life of the sailor is a noble calling in the great household of God'. ${ }^{42}$ This was because Wohlers saw sailors as facilitating trade and the spread of Christianity, and thus the development of Christian nations that would produce and cooperatively trade their various surpluses with one another in a prosperous and peaceful future. This supports Sujit Sivasundaram's claim that 'the quest for an imperial world linked by knowledge and commerce has an evangelical ancestry, ${ }^{43}$

Although Wohlers viewed tilling the soil and Christianity as not just interdependent but outright inseparable, he was absolutely reliant on and at the whim of the ocean; and he knew it. Books, clothes, money and mission assistants all came by sea (eventually), from Bremen and London, and sometimes more distant and mysterious places like Auckland. Discursively, one of his more eloquent and forceful meditations on the nature of science and religion and their relationship invoked his sea-voyage from Hamburg to Nelson in 1842-43. Using this as an extended metaphor, he wrote that, 'No one in the ship doubted that the captain and the mates would find the far-away island of New Zealand in the wide ocean.' However, 'only a few could understand how it was possible.' He continued, 'Their undoubted confidence was therefore faith without sight; but they could understand with their reason that their faith was truth' because in the great commercial city of Hamburg they had seen ships that unloaded goods from and sent goods to points all around the world. 'It was, therefore, clear to reason that the ships could find their way across the seas.' Wohlers argued that the 'conditions are the same with respect to the Christian religion which the Bible teaches us'. He proceeded: 'We cannot explain it at all clearly, but we can understand with our reason that our faith is truth. The great city with its harbour full of shipping is the world with its countries and peoples, and the belief in the Bible shows itself in its operation. ${ }^{34}$

Richard Drayton's exploration of the 'economics of Eden' and the ideology of improvement that was fundamental to the making of the British empire means that we primarily associate him with land. However, he is also mindful of early proponents of Britain's so-called 'Blue Water destiny'. He thus references the fifteenth-century economist and philosopher William Petty, who calculated, in part through reference to the sea-going Dutch, that a seaman was worth three farmers. This is not to suggest that Petty was against agriculture; indeed, he agreed that the husbandman was the pillar of the Commonwealth. It was simply that ships required sailors and ships were necessary if one wanted to 'improve' the world as a whole, which he did. ${ }^{45}$ 
The key to understanding the British empire is therefore an appreciation of the sea and ships, for through that we can begin to fully understand Drayton's description of the empire as a 'haphazard system held together by an alliance of the farmer, colonist, merchant, religion, and science' ${ }^{46}$

\section{'Bicultural' Bluff?}

As foreshadowed in the introduction, I argue that looking at people and practices in Bluff beyond the colonial encounter helps to illuminate the earlier epoch in at least two ways. Firstly, residual Māori life-ways, many of which still exist in the present day, can be read back into the colonial past and used to cross-reference the archive or help fill its silences. Secondly, residents of the town who were neither Māori nor Pākehā are more retrievable than their antecedents who were present in the south from the beginning of sustained 'European' contact but about whom we ultimately know very little. Bicultural history tends to ignore these people or equate them, as non-Māori, with Pākehā. Both responses are inadequate. Let me mention one maritime subaltern to illustrate my point.

In 1959, Felix Devalon (pronounced Devalong) died in Bluff aged 94. ${ }^{47}$ Mr Felix, as he was known, was born in Dominica in the West Indies. After losing his parents at a young age, Mr Felix went to sea and sailed across the world for 25 years before landing in New Zealand, at Picton, about 1890 . He then walked from Blenheim to Bluff, where he based himself, working as a wharfie for the following 48 years. He recalled that Bluff as he found it was still covered in tall bush, which teemed with native birds, and 'there were a lot of Maoris'. Life in Bluff was not always easy and, as with a number of Kāi Tahu men, when 'things got hard on the wharf' Mr Felix fished off Ruapuke, crewed ships to Macquarie Island, or worked in shearing sheds. None of this seems to have been as bad as his visit to Calcutta as a mess boy on a salt ship, though. He described that place as 'the ugliest and most stinking place - no good'. As with a number of seamen, Mr Felix never married. As he told a journalist on his 90th birthday: 'What good is a wife to a sailor?' He could look after himself and do all his own chores, including all of his own cooking on a little crib stove that was 'highly polished'. The reporter further noted that Felix's culinary repertoire included 'macaroni the Italian way, ${ }^{48}$

Just as colonial tides brought non-Europeans like Mr Felix to Bluff, they also carried several Bluff-raised Kāi Tahu away. One such person was William Tihope 'Billum' Spencer, a great-grandson of Bluff's proverbial founding father, the former soldier, sealer, whaler and trader James Spencer who died and was buried at sea in 1846 on a voyage back to Bluff from Australia. ${ }^{49}$ Billum served as a seaman with the Foreign Naval Service on 
troop and hospital ships during World War One and later joined the British Admiralty - travelling the world and 'writing letters back home with tales of exotic destinations. ${ }^{50}$ Unlike many of his tribal forebears who boarded sealing or whaling ships in the pre-colonial Tasman world and never returned home, Billum did. A cause for this was muttonbirding. The tītī harvest was 'so long a part of his life' that it 'over-rode the wanderlust of a sailor': 'No matter where in the world he had last been heard of - and once it was China - he would turn up at Horomamae [one of the Tìtī Islands] just like a homing pigeon!' ${ }^{51}$

Billum later worked on the government steamer Hinemoa servicing New Zealand lighthouses, and through that he met and eventually married Lena Smith of Moeraki, also of Kāi Tahu descent. This is but one example of the ongoing process of genealogical tightening within the iwi that needs to be read alongside the story of interracial marriage. Despite his marriage and the received gender roles that that commonly entailed at the time, Billum, like Mr Felix, 'so long at sea without a mother to fuss over him . . . did all his own mending and darning. When something needed attention, he was quite happy to get out his "diddy bag", thread up a needle, and sew, mend or darn shirts, trousers and socks'. Ultimately, though, Billum's descendants remember him for his 'seasonal routine' - tending to his large vegetable garden and going oystering and muttonbirding - 'the pattern a secure cocoon around his life'. ${ }^{2}$

Billum's uncle, William Hautehe Spencer, also went to sea. After working at J.G. Ward's Bluff grain store for six years and 'unable to ignore the call of the sea', William signed on on a sailing ship that traded around New Zealand, Australia, the Pacific and Calcutta. He did this for seven years before realizing that if he did it for too much longer "he would be too restless to settle anywhere'. ${ }^{53}$ Returning to Bluff, he worked on the wharf and was a Southland representative rower. He later married Christina Goomes from Rakiura, a fellow half-caste with a similarly sea salt-encrusted whakapapa. Born to a Kāi Tahu mother and a Portuguese father originally from the Cape Verde Islands, Christina kept a home which was surrounded by magnificent flower gardens on the outside, and, like so many others in the port, smelled of fresh baking and sizzling muttonbirds on the inside..$^{54}$

It is hard to say whether Billum and Lena's marriage, like William and Christina's, and the marriages of many others like them (such as my own great-great-great grandparents, John and Noki Haberfield), was ultimately due to their shared genealogical, geographical, or cultural backgrounds. It is probably impossible to separate these strands out anyway. Likewise, while I hesitate to say that these tūpuna and their descendants saw themselves as neither wholly Māori nor wholly Pākehā, but distinctly coastal, the whole 
being greater than the sum of its parts ${ }^{55}$ there may yet be some truth in this line of thinking. In any case, the key point to note for now is that proverbial birds of a feather flocked together, thus prolonging and calcifying a suite of southern Māori life-ways.

\section{Our sea behind them ${ }^{56}$}

The thing that secured Bluff's importance to settler society above all else, and employed a lot of Kāi Tahu between the 1880s and the 1980s, was the butchering and freezing of Southland's sheep and beef, and their export to England. This is somewhat of an irony.

The first live sheep into Southland were landed at Bluff by agrarianfocused European settlers in the mid-1850s and driven inland onto nascent farms. Initially at least, these farmers were dependent on coastal-based halfcaste Kāi Tahu like William Te Paro Spencer, Billum's Pōua (grandfather), to guide them along the harbour shore, tidal estuaries and creeks and into the interior. The point to note here, though, is that William returned to Bluff and the farmers stayed inland, and it has largely been that way ever since. Not many rural-raised 'respectable' Pākehā have ever lived, or lasted very long, in Bluff. ${ }^{57}$ Even that maverick Mick, Bluff's best son, Sir Joseph Ward, really only came back to his hometown to be buried; he was in Wellington with his horses Ruapuke and Awarua for the most part. Likewise, not many southern Māori have ever owned farms in inland Southland. It is true even now. Very few Māori live in the likes of Te Anau or Winton. Meanwhile, there are large numbers of Māori in Bluff and Riverton. As Beattie noted in 1944, 'There are probably more residents with Maori blood in Bluff than in any other town in the South Island'. ${ }^{58}$ In 2006, $43 \%$ of Bluff residents self-identified as Māori, compared with $11.8 \%$ for the Southland region as a whole and $15 \%$ for all New Zealand. ${ }^{59}$

Anyway, I suggest that we think about Kāi Tahu communities, altered by the imperial encounter, as standing on the coast of Murihiku looking out to sea in the mid-nineteenth century. They observe the arrival of shiploads of agrarian Europeans and goldminers on its shores and help land them both. These arrivals then quickly head inland and they and their descendants have had their backs to the coast, and Kāi Tahu, ever since. Southern Māori on the coast; southern Pākehā inland. I am of course generalizing, but there is a truth in what I am saying. And yet these two groups came to be in a fascinating symbiotic relationship with one another. Indeed, the idea of 'symbiosis between land and sea' lies at the heart of Pearson's understanding of the littoral. ${ }^{60}$ The interdependence I refer to, more than anything else (shearing and rural labouring, for example) centres on farmers who sent their stock to Bluff to be slaughtered, frozen and shipped overseas from 1883 onwards. 
Many Kāi Tahu, men and women, had jobs at 'the works'. In the midtwentieth century they attracted large numbers of men from the North Island, and later Cook Islands and Samoa, in ways that Hau'ofa would recognize immediately. In short, for the best part of a century Southland's Pākehā farmers - people central to the economic and social marginalization of Kāi Tahu - nonetheless enabled a lot of Kāi Tahu to stay in Bluff and retain traditional practices, values and social structures. This included the maintenance of ahi kā over various places and activities, including, as we have seen, the Tîti Islands. I am as yet unsure of when it first emerged, but in the twentieth century at least the works had a 'muttonbirders' chain'. This started and finished early in the kill season so that the plant's 'birders' could more easily fit the tîtī season into their year. All of this was, of course, underpinned by an empire superstructure and policy of imperial preference.

\section{Conclusion}

At one stage of my childhood, the ceiling above my bunk in the house on our family's Tītī island, Pikomamaku-nui, was a shiny metallic sarking. I learnt that this started off as a barrage balloon in London during the Blitz. After the war it was converted into a hatch cover for a cargo ship. It then 'fell' off that ship in Bluff, possibly in exchange for a feed of oysters or tîtī with a crewman who was that way inclined. Our family then used it to cover deck cargo, including pōhā-tîtīi, in the course of travelling to and from the Tîtī island on inshore fishing boats. Years later this treasured tarpaulin became roof sarking. This silvery sheet, and the continued existence of pōhā - which my grandfather's uncle deployed when helping to smuggle illegally-harvested sealskins to London in the late 1930s - lead me to suggest that Māori groups responded to colonization and the consequences of colonial marginalization in more dynamic ways than we realize or admit. If we are serious about charting the nature and extent of the resulting Māori modernities in any detail, then it seems to me that ports are a good place to start looking. In so doing, though, we will probably have to jettison some of the current modes we use to think through Māori history. In their place, and like the tūpuna we study, we should incorporate novel ideas, if they are useful, from abroad. Above all else, the resultant scholarship should be both smart and strong. As our grandfather - a muttonbirder, boat-builder and former wharfie - still instructs us when placing tōtara bark around pōhā-t̄îti: 'best side to London'.

1 Paul Diamond, A Fire in Your Belly: Māori Leaders Speak, Wellington, 2003, p.14.

2 'Jet Airliner', Steve Miller Band, 1977.

3 Diamond, p.12. 


\section{Maritime Culture in Colonial Southern New Zealand}

4 I use Euroamerican as a shorthand term to refer to the Europeans, Euro-Americans, Native-Americans, African-Americans, South Asians and even Aboriginal Australians who featured in southern New Zealand's imperial encounter. Put differently, I use the term in an epidemiological rather ethno-geographic sense.

5 Kerry Howe, 'Two Worlds?', New Zealand Journal of History (NZJH), 37, 1 (April 2003), pp.50-61.

6 Damon Salesa, public lecture at the University of Otago, 2005.

7 Epeli Hau'ofa, 'Our Sea of Islands', in Eric Waddell, Vijay Naidu and Epeli Hau'ofa, eds, A New Oceania: Rediscovering Our Sea of Islands, Suva, 1993, p.6.

8 Tipene O'Regan, 'Old Myths and New Politics: Some Contemporary Uses of Traditional History', in The Shaping of History: Essays from the New Zealand Journal of History, Wellington, 2001, p.19.

9 Peter Gibbons, 'The Far Side of the Search for Identity: Reconsidering New Zealand History', NZJH, 37, 1 (April 2003), pp.38-49.

10 Frederick E. Hoxie, 'Ethnohistory for a Tribal World', Ethnohistory, 44, 4 (1997), p.597.

11 After Philip J. Deloria, Indians in Unexpected Places, Kansas, 2006.

121856 being when Bluff harbour was declared an official port of entry, and 1907 when New Zealand became a self-governing Dominion. It should be noted that between 1857 and 1 April 1917 the Bluff township was officially known as Campbelltown. However, this did not ultimately suit locals, who continued the pre-colonial European tradition of referring to it as The Bluff. Bluff is used throughout this article.

13 Michael J. Stevens, 'Muttonbirds and Modernity in Murihiku: Continuity and Change in Kāi Tahu Knowledge', PhD thesis, University of Otago, 2009.

14 Frances M. Steel, 'Maritime Mobilities in Pacific History: Towards a Scholarship of Betweeness', 2010, http://ro.uow.edu.au/artspapers/243, 200.

15 Tamson Pietsch, 'A British Sea: Making Sense of Global Space in the Late Nineteenth Century', Journal of Global History, 5 (2010), pp.423-46.

16 Steel, 204.

17 Michael N. Pearson, 'Littoral Society: The Concept and the Problems', Journal of World History, 17, 4 (2006), pp.353-4.

18 Erik Olssen, A History of Otago, Dunedin, 1984, p.28.

19 Ibid., pp.28-29.

20 Murray McCaskill, 'Otago Province or Provincial District', An Encyclopaedia of New Zealand 1966, at Te Ara - the Encyclopedia of New Zealand, http://www.teara.govt.nz /en/1966/otago-province-or-provincial-district/5, accessed 1 August 2011.

21 The Ngāi Tahu 'Blue Book', a census of Kāi Tahu people alive across the entire takiwā (tribal area) in 1848, lists fewer than 1350 names.

22 Howard Robinson, The Development of the British Empire, Boston, 1922, p.253

23 Angela Wanhalla, In/visible Sight: The Mixed-Descent Families of Southern New Zealand, Wellington, 2009.

24 Herries Beattie, Our Southernmost Maoris, Dunedin, 1954, p.8.

25 Bill Dacker, 'The People of the Ahikaaroa', in Paul Sorrell, ed., Murihiku: The Southland Story, Invercargill, 2006, p.54.

26 J.E. Bremer, Those Sheltering Hills: A History of Bluff, Invercargill, 1986, p.51. 


\section{Journal of New Zealand Studies}

27 Herries Beattie, Traditional Lifeways of the Southern Māori, ed. Atholl Anderson, Dunedin, 1994, p.177.

28 Probably the Second Boer War. It is also possible that the freezing works building was actually decorated on 'Mafeking Day' (a celebration of the Relief of Mafeking, a famous British victory in the Second Boer War, in May 1900), as several ships in port at the time marked this event. See Maurice Skerrett, Waterfront: Reminiscences of a Bygone Era in the Port of Bluff, Invercargill, 1997, p.27.

29 'The Fracas at Bluff', Southland Times (ST), 7 August 1901, p.2.

30 'At Campbelltown', ST, 2 June 1882, p.2.

31 Beattie explained that 'The old Maori hostel at the Bluff was near the freezing chambers and taken down. The Maoris claimed it as a landing place but it was found that they had no title, so the Government built a place further back for the use of Native travellers.' Herries Beattie, Maori Place-names of Otago, Gore, 1954, p.53.

32 Ibid. For an amusing story of this building's 'house-warming', attended by 'tribes' from 'as far remote as the Waitaki', see Herries Beattie “"Old King Toby” (8)', in 'Historical notes collected to write a book about Bluff', n.d., MS-582/I/7, Hocken Collections, Dunedin.

33 This commentator, Dorothy Wiseman, also noted that 'On the outside walls of all their houses may be seen hanging the kelp bags in which the mutton-birds, those highly-prized delicacies, are stored.' Dorothy Wiseman, 'Our Southern Coast', New Zealand Railways Magazine, 11, 10 (1 January 1937), p.32. Wiseman was told that most southern Māori 'could trace their first white ancestor to one of the whalers who once swarmed about these southern shores' (p.35).

34 Pauline Jorgensen, Love, Laughter and Oysters, Christchurch, 1998, pp.1-4.

35 Ibid., p.17.

36 J. Lort Stokes, 'Survey of the Southern Part of the Middle Island of New Zealand', Journal of Royal Geographic Society, 21 (1851), p.28.

37 Skerrett, p.21.

38 Gibbons, p.41.

39 Tony Ballantyne, 'On Place, Space and Mobility in Nineteenth-Century New Zealand', NZJH, 45, 1 (2011), p.57.

40 Otago Witness, 30 November 1899, p.1.

41 Evangelist, 7, 1 February 1875, p.1.

42 J.F.H. Wohlers, Memories of the Life of J.F H. Wohlers, Missionary at Ruapuke, New Zealand. An Autobiography, trans. John Houghton, Dunedin, 1895, p.61.

43 Richard Drayton, Nature's Government: Science, Imperial Britain, and the 'Improvement' of the World, England, 2000, p.45.

44 Sujit Sivasundaram, Nature and the Godly Empire: Science and Evangelical Mission in the Pacific, 1795-1850, Cambridge, 2005, p.3.

45 Wohlers, p.61.

46 Drayton, p.59.

47 Ibid.

48 His headstone says that he was 96 years old. 'Old' Bluff Cemetery, Lagan Street, plot $12 \mathrm{~B}$. 


\section{Maritime Culture in Colonial Southern New Zealand}

49 'Felix Devalon, who has sailed seven seas, celebrates his 90th birthday next Sunday', 5 October 1955, cit. in Early Bluff: the Newspaper of the Bluff History Group, 16, October 2009, p.4.

50 Georgina Ellis, Time \& Tide: Ramblings, Recollections and Reminiscences of the Spencer Family, Invercargill, 1999, p.16.

51 Ibid., p.76.

52 Ibid.

53 Ibid., p.78.

54 Ibid., p.110.

55 Ibid., p.111.

56 Pearson, p.357.

57 After W.H. Oliver, 'The Future Behind Us: The Waitangi Tribunal's Retrospective Utopia', in Histories, Power and Loss: Uses of the Past - A New Zealand Commentary, ed. Andrew Sharp and Paul McHugh, Wellington, 2001, pp.9-29.

58 Pearson would probably see this as evidence of Bluff as a truly littoral space, which he contrasts with 'port cities' where elite inland norms took root. Pearson, p.356.

59 Beattie, Place-names, p.53.

60 'QuikStats About Bluff', 2006 Census, http://www.stats.govt.nz/Census/2006Census HomePage/QuickStats/AboutAPlace/SnapShot.aspx?type=au\&amp;ParentID=1000015 \&amp;ss=y\&amp;tab=Culturaldiversity\&amp;id=3612100, accessed 30 July 2011.

61 Pearson, p.354. 
Journal of New Zealand Studies 